\title{
1. Settler Economies and Indigenous Encounters: The dialectics of conquest, hybridisation and production regimes
}

\author{
Christopher Lloyd
}

\section{Against Over-Generalisation: For description in social science history}

The socioeconomic histories of settler societies with their conquests, impacts, articulations, fusions and hybridisations are a fraught field for research, with a wide range of conceptualisations and debates, and one with significant material effects in the present. Few areas of contemporary social science history have more direct social significance. History wars, governmental Indigenous policies, socio-anthropological research and political debates are all directly affected by conceptual/scientific and ideological debates. Furthermore, the literature on settler economic history, in contrast with that of social and cultural history, has been somewhat lagging in this conceptual debate. ${ }^{1}$ This chapter is a discussion of the development, meaning, use and usefulness of the central but controversial concepts of 'conquest', 'hybridity' and 'production regimes' to the field of settler-Indigenous economic relations and their consequences. I argue we need all these concepts and several more and that the concept of 'hybridity' must be part of this bigger set of concepts - depending on how it is specified and used-if it is to carry the weight placed on it. In particular, it is argued here that the concept of 'hybridity' — now extensively used in cultural studies and especially post-colonial studies - is useful for this field but also potentially overgeneralising and misleading in its application. The danger is, I argue, that the use of 'hybridity' could obscure as much as it illuminates if it is too generalised. Surely not all socioeconomic articulations, blendings, mergers or fusions are hybridisations. If they are then the concept loses specificity and power because of over-generalisation.

The problems of over-generalisation and reification bedevil the socio-historical sciences, especially those branches, such as economics and sociopolitical 'science', that rely overly on aggregated statistical data series (most of which are

1 The research for this chapter has been supported by Australian Research Council Linkage Grant LP0775392, in association with the National Museum of Australia. I thank Jon Altman for comments on an earlier draft. 
compiled by official agencies and via processes devoid of real research), flawed statistical techniques (devastatingly criticised in Ziliak and McCloskey 2008), and very general concepts that are used as substitutes for detailed examination of cases. The aggregating socio-historical sciences pay far too little attention to the empirical 'field' research that is necessary to description and understanding. On the other hand, those branches of socio-historical research, particularly history and sometimes cultural studies, that concentrate only or mainly on description and make insufficient generalisations based on quantitative data, comparison and general concepts are not able to provide adequate analyses. One essential task, then, is to combine general concepts, such as 'hybridity' and 'production regimes', with detailed descriptions of particular cases. As W. G. Runciman argued and demonstrated persuasively in his Treatise on Social Theory, description is a fundamental task of social science. How descriptions are generated and framed is essentially via the formulation and use of ideal typical concepts whose meaning is fixed by being

intelligible by reference both to what 'their' experience is like to themselves and to the analogous experience of others to which it is being likened. It can however, equally well be done from either end. It can be formulated either as a hypothetical set of circumstances, or form of behaviour, or mode of attitude or feeling from which an adjectival concept is then derived, or as an adjectival concept implying an extreme instantiation which would be applicable if, and only if, a hypothetical state of affairs, etc. were to be observed. (Runciman 1983:291)

The descriptive ideal type must be such that while being ideal, it contains nothing impossible in the sense of being simply an explanatory abstraction but rather is a general-limit case of what actually is possible. 'Hybridity' should be used in such a manner - as a descriptive generalisation that aids in describing and understanding the nature or characteristics of a particular real social form. An explanatory abstraction, on the other hand, such as 'production regime', is a concept that is used to explain the causal processes of particular cases.

\section{The General Meaning of Hybridity}

The original use of the concept of 'hybridity' - a word of ancient Latin originas developed in the genetics of animal and plant breeding and the biological sciences more widely, refers generally to the mixing or blending of organisms through interbreeding to produce new, sometimes very vigorous, organisms. But in some cases one consequence of such selective breeding is infertilitythat is, the inability of the new, artificially created organism to reproduce itself, often because of slightly incompatible chromosomal structures of the parents. 
This is often the case with hybrid crop species and sometimes with interspecies breeding among closely related animals such as horses and donkeys, lions and tigers, goats and sheep. On the other hand, hybrid breeding within animal species, such as cattle, does not usually result in infertility because the breeding is only to select certain characteristics of alleles through crossbreeding and even through a degree of deliberately incestuous selective breeding. It is also important to know that hybridity is a naturally occurring phenomenon in the plant kingdom, especially at species boundaries and among members of a genus. In this case, the resulting plant species are not able to reproduce through sexual processes but simply by spreading through rhizomes so that all the supposedly different organisms in a specific area are actually the same organism.

A specific form of hybrid is a chimera, which is the transgenic result of the genes of one organism or species, such as a bacterium, being transposed into the germ line of another, such as a plant, which produces a specific genetic innovation, which, in artificial breeding, has a desirable effect on that organism's survivability or behaviour.

The transfer of 'hybridity' into the social sciences - a sort of hybridisation of research concepts in a sense-has been influential but controversial. The concept of 'hybridity' is now widely and centrally employed in the broad field that includes Indigenous studies, post-colonial studies, diaspora studies and settler-society studies. Use is also made in literary studies, management theory, economic theory, geographical theory, technological theory, car technologies, robotics and, most strikingly, in conceptualisations of human-technological convergence through the development of cyborgs. In all these areas it seems the basic assumption - often without much conceptual explication - is that the mixing or blending of types, genres, structures, logics or processes results in something that is not just novel but also has emergent properties and even existential vigour that surpasses the parents. Of course, strictly speaking, many of the entities described as 'hybrids' do not actually fit the specific definition, being rather syncretics, such as cyborgs, rather than true hybrids.

A fundamental difference between biological and social hybridity is in the degree of difference in the nature of the 'parent' entities. Biological hybridity is of closely related species and subspecies. Social hybridity, on the other hand, occurs between very different social forms. This is crucial to the concept. Articulations and fusions of closely related social forms do not usually result in hybridity but simply fusions or mergers. Hybridity often has the connotation of partial overlap for specific purposes between very different social forms while much of the 'parent' formations remains apart from the hybridised area of activity and the distinct contributions by the parents can be identified, at least 
while it remains a hybrid activity or form. That of course raises the key issues of stability and the persistence of hybrids. Are they relatively stable structures or dynamic and perhaps unstable transitional forms?

Therefore, the key implicit ideas in all these areas of the social sciences that claim to be dealing with hybridity are about 'adaptation', 'viability', 'emergence' and even 'dialectic'. Hybridity is taken to be a state or outcome of mixing and blending of hitherto distinct and often very different entities and structures that combine elements from the parental contributors in ways that produce sometimes surprising or divergent but certainly viable new entities, processes and structures. Viability is essential to the concept and description of cases, for without it the new entities and structures would obviously not exist. This is not simply a tautology, for viability carries the idea of continuous existence and some degree of autonomous power through time. A hybrid outcome becomes a new practice or structure and so takes on a life of its own with a degree of autonomy in the sense of enabling human agency and structural reproduction. Hybrid outcomes are not simply syncretic entities or systems that simply cobble together features of the parents, like famous mythical chimeras such as centaurs, mermaids and minotaurs. Furthermore, hybrids are not simply articulations, which are usually exchange relationships through which more or less independent societies enter relations of greater or lesser co-dependence. Such articulations might lead to hybridisations but not necessarily, at least in the short run (cf. Austin-Broos 2003).

Thus, for a genuine hybrid to come into being there must be emergent properties that arise from but are not reducible to particular characteristics of the parents. Hybrids are indeed real things with properties and powers of their own, which have to be described in their own particularities. Sooner or later, we can surmise, most hybrids cease to be such and become simply new, integral formations, cultures or production regimes. This, we can say, is one of the fundamental logics of socioeconomic history in the sense of the evolutionary process of societalisation in the very long run.

Two further general issues about hybridity need to be raised: degeneracy and the possibly metaphorical nature of the concept. Natural plant hybrids could be viewed as degenerates in the sense that the new species has lost its power of sexual reproduction. On the other hand, this can be seen as a viable evolutionary strategy. Of course, judgments of 'degeneracy' are unwarranted in biology for that idea implies a natural teleology, which is a false step. The idea of progress has bedevilled biology and should also be avoided in the social sciences, especially if it springs from a pernicious teleology. 'Degeneracy' in social science has roots in racism and manifest destiny. The essential point about hybridity is its adaptiveness and agency. These are not metaphorical ideas. 'Hybridity' and its associated concepts are descriptive-analytical in force and seem to be necessary to social explanation. 


\section{Conquest, Articulation, Fusion, Survival, Agency}

The usefulness and power of 'hybridity' in social description and explanation depend, then, I argue, on its implicit or explicit integral connection with other key concepts or ideas, especially 'conquest', 'articulation', 'fusion', 'survival' and 'agency'.

Conquest has been a fundamental force of human history ever since the relation of objective property emerged from what Marx called the 'historic process' of production, which led to the separation of the primordially unified inorganic conditions of human existence from the active being of humanity. The original form of communal human sociality was a natural (that is, not historical) presupposition of existence (Marx 1986:411-13). But ever since the advent of pastoral and agricultural societies and therefore of social classes, human societal evolution has been driven to a significant degree by collective violence over the conditions of production. Large-scale resource competition, class divisions and conflict led to imperialism and the near universality of slavery. Conquests of land, people and cultures and the resulting destruction, massacres, fusions and hybridisations have been long-running themes of millennia throughout the world. The history of English social structure, language, culture and governance from even earlier than the Roman conquest is a good example of this process. Conquests can have many outcomes, from complete annihilation of peoples and cultures to absorptions and fusions (such as has occurred many times in England), including mestizoisations, hybridisations and accommodations that permit relative autonomy of the conquered. All of these processes occur over extended time scales. In every case, key questions concern the specific contexts and processes that lead to specific outcomes and the degree of autonomy and agency of subordinated peoples. In all outcomes from conquest there is, of course, a hierarchy of dominance and subjection.

The imperial conquest, settlement and local historical processes of what became the settler, creole and mestizo societies of the European empires from the early sixteenth century onwards (to say nothing about Asian and African empires in medieval and early modern times) produced many varied social outcomes by the twentieth century. Not all indigenous peoples of the settler world were either exterminated or enslaved, but many who were not were at least marginalised, especially in the sparsely populated temperate zones that became settler societies. Settler-indigenous conflict and outcomes evolved in many ways; nevertheless, the facts of conquest and transformation were shared by all.

Perhaps hybridisation can best be understood as a strategy - an agential strategy of survival and adaptation and even progress in response to processes of collision, conquest and domination. Thus, key questions are of self-activation, 
domination, subjectivity and universal logic of cultural and economic adaptation and survival. Is hybridity perhaps often the only possible strategy for cultural and social survival under imperialism and globalisation? This is probably so, for the power of imperial/global forces is such that the whole world is now enmeshed into a single economic system and the hegemony of 'global culture' is very strong. The logic of a global world is the logic of universality and sameness. Hybrid forms have to be developed if local autonomy is to be maintained to some degree. This applies to all societies, not just indigenous ones.

Is the concept of 'hybridity' too general in its application? If the development of hybrid socio-cultural-economic formations is a phenomenon of such universality, its application to a particular case might not tell us much about it beyond a truistic description. Hybridisation, it can be argued, is a universal consequence of societal evolution because the evolutionary process of societalisation in the long run has always resulted in hybridisation through the conquest or merger of societies (what can collectively be described as social collisions). Unlike the evolution of species, which is a one-way process of separation that cannot be reversed once the process has resulted in new species, the evolution of societies through both evolutionary drift and societalisation is sometimes 'reversible' in the sense of reversion leading to something like the previous state and, moreover, societies can merge (often through conquest) to form new societies that incorporate features and components of the previous separate formations. These merged forms are often described as hybridisations, which is a particular form of merger that preserves essential features of the previous forms. In other words, the issue is not whether hybrid formations emerge from social collisions, which they often do, it is to do with the forms and features of the merged outcomes.

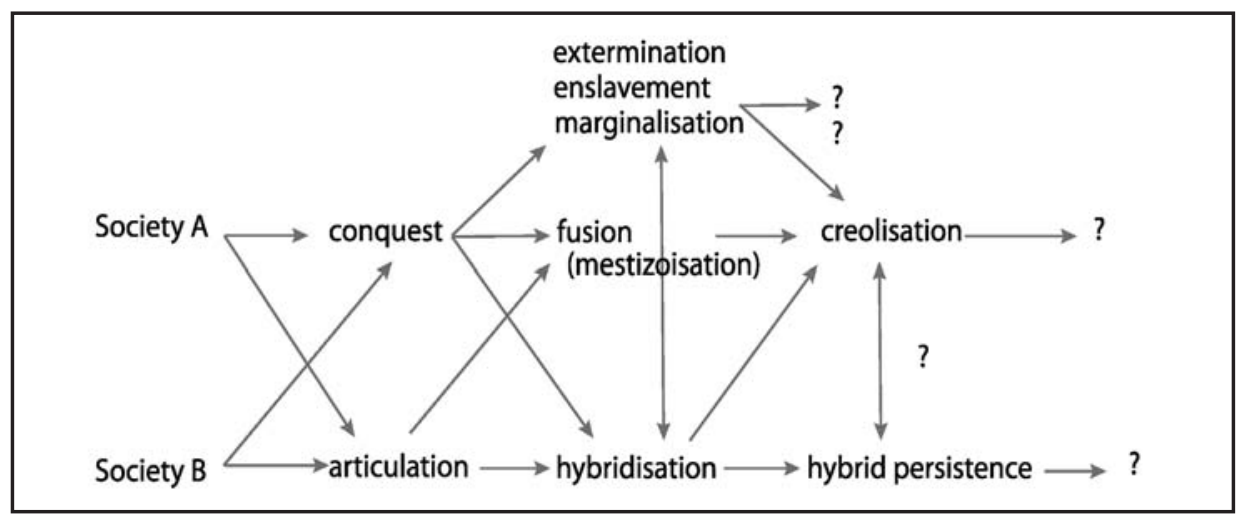

Figure 1.1 Conceptual matrix of conquest and articulation 


\section{From Settler Production Regimes to Globalisation}

Kraidy (2005) has described hybridisation as 'the cultural logic of globalization'. Can we extend this idea to say that hybridisation is a (not 'the') logic of the economic history of all settler-indigenous relations within settler societies, at least, and perhaps within all economies undergoing globalisation? If globalisation is the process of global integration such that local differences and local autonomies become hybridised or fused then indigenous communities and peoples and other marginalised groups and regions might have little choice about their futures. Resisting globalisation today is as difficult as resisting settler invasions in earlier times. ${ }^{2}$

In the neo-European settler domains ${ }^{3}$ from the eighteenth century onwards, various outcomes between settlers and indigenous people were experienced that resulted in the emergence of new production regimes involving the articulation of settlers and indigenous people. These articulations were usually quite distinct from the dominant relations of production between land, capital and wage labour in the 'mainstream' settler-capitalist economies. Indigenous people were at best marginalised by the conquest of their lands in 'the great land rush' (Weaver 2003), and out of their marginalised state certain hybrid forms sometimes emerged. Numerous cases of what can be described as creole and hybrid economic and cultural processes can be identified in the historical and contemporary literature on North America, southern South America and Australasia.

Settler societies have certain special characteristics that have set them apart over the past couple of centuries (cf. Belich 2009; Denoon 1983; Lloyd and Metzer 2012; Weaver 2003). A fundamental characteristic has been and is still the settler-indigenous relationship, which is quite different from other intercultural and interracial relationships in other forms of colonial and post-colonial society of the modern European imperial age. ${ }^{4}$ This characteristic, which resulted from

2 Indigeneity is not just a phenomenon of settler societies. First peoples still exist as hybridised societies within many European, Asian, Middle Eastern and African states.

3 These regions in the temperate zones - mainly in the Americas, Australasia and Southern Africaare distinguished by their particular interconnection of land, capital and labour of an emergent and then developed capitalist kind by the mid-nineteenth century. They contrast with tropical colonial zones where coerced plantation labour was the dominant form and colonial zones where indigenous peasantries remained the dominant economic form. In settler societies, the settler-capitalist form became dominant with strong articulation to the world market via large flows of capital, free labour and commodities. Here indigenous people were initially marginalised or even exterminated (cf. Belich 2009; Denoon 1983; Lloyd 2012; Lloyd and Metzer 2012).

4 The relatively sharply defined ethnic distinction between the descendants of settlers (or immigrants) and indigenous people that we find today in the United States, Canada, Argentina, Australia, New Zealand and Israel is not found in other parts of Latin America where mestizoisation has been the norm. But it could be the case that the degree of mestizoisation is greater in the United States, Canada and Australia than is generally recognised. An interesting case is Chile, a typical settler society in many respects, in which the majority of people are now of mixed settler-indigenous lineage but only a minority self-identifies as indigenous. 
the dispossession of indigenous people and the expropriation of most of their lands, has been the foundation of a distinct capitalist production system within the capitalist world economy. In tropical plantation colonies until the late nineteenth century, the labour supply system was typically one of full coercion of imported slaves, such as in the Caribbean/Gulf of Mexico and northern Brazilian regions, or enslaved indigenous people, such as in the Andean region, or semi-coerced, indentured labour systems as in the Pacific and Indian oceans regions. In the settler societies, indigenous peoples who survived were usually highly marginalised, surviving on remnant reserved lands and attempting to maintain traditional ways of life. The majority was not proletarianised. As the twentieth century progressed, they became increasingly state dependent. Reassertion of traditional rights and development of hybrid production became a global movement in the late twentieth century.

'Production regime' is a useful concept with Marxian and Polanyian ancestry that refers to the complex formation of a whole society's economic and regulatory structure and processes, particularly its labour control, management and technological subsystems, and how these all interconnect. A production regime has several levels of complexity and integration, including various economic sectors, industries and regions, and state regulatory systems. The whole is integrated and regulated by state and private formal control, by physical infrastructure, as well as by substantive social processes (cf. Lloyd 2002, for more detail on regulatory regimes of political economy).

The idea of a regional or national 'production regime' is of the interconnections between the various forms of production, each of which has a substructure of technical, organisational, social and cultural arrangements that is necessary for the production and distribution of the means of material life and of commodities. In turn, each form of production is connected to a series of other forms of production in some sort of cluster or hierarchy, which together constitute a whole regional, national and even global system of economic interdependence. Capital, labour, materials, commodities, ideas and even institutional forms flow within and between them. Each form of production has its own structure, dynamic and trajectory. But within the whole regional or national economy, as regions and nations grew in strength and integration over recent centuries, there developed an increasing degree of systemic integration of local forms of production so that an integrated system of capitalist dominance emerged by the early nineteenth century within settler societies, predicated strongly on a world market. These zones and new colonial and nation-states became very intermeshed into the world commodity, capital and labour flow systems. The possibilities of non-capitalist and non-globalising forms and zones within these societies were increasingly closed off as the nineteenth and twentieth centuries wore on. The space for indigenous and other local autonomy began to 
disappear. It seems there were only three possibilities left for most peoples by the mid-twentieth century: complete absorption into the dominant society and culture, albeit in an impoverished and marginal way; some form of creolisation in marginal areas; and hybridisation. All these forms can be found within settler societies today.

Indigenous-based hybrid production forms have to be understood, then, as subordinate and dependent modes within larger capitalist production regimes. Rapidly changing capitalism and the world market determine the possibilities. Nevertheless, socio-cultural and economic hybridisations by indigenous people have to be understood as strategies for adaptation, survival and agency. The impetus must spring largely from the needs and aspirations of indigenous peoples, for the globalised capitalist context in which they must move contains no such imperative. ${ }^{5}$

\section{Hybridity in Australian Indigenous Contexts: Two descriptions re-examined}

The use of 'hybridity' to describe and analyse Australian Indigenous social situations and processes has been fruitful and we can say that a research-based policy program has now emerged, centred on Jon Altman's and others' works. ${ }^{6}$ There have also been other instances of settler-Aboriginal accommodations that we can perhaps redescribe as cases of hybridity (cf. Lloyd 2010b). Of the latter kind, one in particular stands out as worthy of re-examination in this mode: James Boyce's Van Diemen's Land (2009). In the light of the foregoing discussion, we can make some constructive commentary about Boyce's historical account and also Altman's research and policy program.

The story described in Boyce's Van Diemen's Land (2009) was of an emergent frontier and unofficial 'occupation' of areas beyond the narrow confines of state-directed settlement in the early decades of Van Diemen's Land history. A kangaroo and dog economy emerged from about 1808 in the grasslands and woodlands of the Midlands region. Boyce describes an overlapping and technologically convergent economy of convicts and bushrangers, on the one hand, and Aborigines on the other. By 1813, cattle and sheep grazing began to replace kangaroo hunting as the main source of meat for the rapidly growing colony. By 1820 an export trade in meat and even limited numbers of livestock was flourishing. The livestock-owning and management system was largely one of free-ranging stock proprietors or share farmers herding their own animals on

5 This seems to be the contention of Noel Pearson in his recent writings (Pearson 2009).

6 See Altman (especially 2005a, 2005b, 2005c, 2007). 
extensive and rich grazing lands (Boyce 2009:68-72). Before the early 1820s, the power of the local state authorities was very weak or even non-existent in the frontier pastoral areas that were effectively controlled by bushranging gangs and Aboriginal clans. While it seems from Boyce's work that there was ongoing but limited miscegenation and violence between Europeans and Aborigines, in the period after 1808 there was an emergent structure of commercial interactions between four groups - bushrangers and convicts (sometimes indistinguishable), Aborigines, the emergent stock-owning capitalist elite, and the state-that could be described as hybridity. The hybridity seems to have existed essentially at the intersection of the Aboriginal system of supplying kangaroo products and later hunting dogs and the European bushrangers and shepherds who were interested in on-selling these products to the state and to the free market. These Aboriginal people became, we could hypothesise at least, hybridised in their economic relationship with the European colony in these early decades of settlement, and it seems a rough modus vivendi existed on the frontier of what is now eastern and Midlands Tasmania.

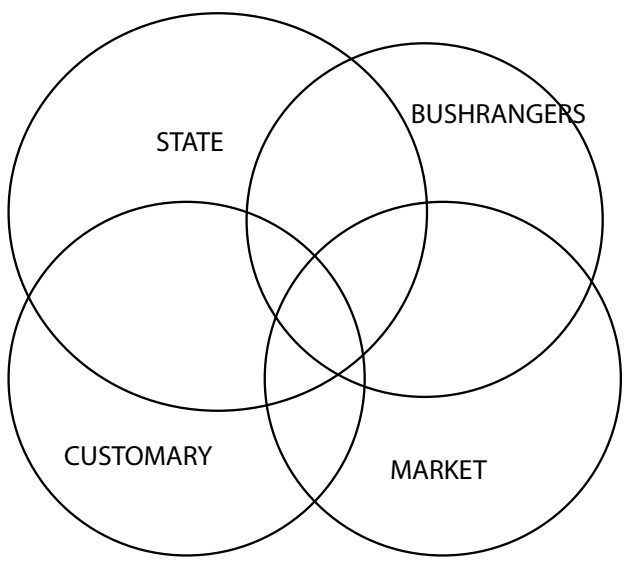

\section{Figure 1.2 The production system of Van Diemen's Land (inspired by Altman and Boyce)}

The hypothesised hybrid production regime of early Van Diemen's Landsupplying kangaroo products and dogs - existed within and was made possible by the nature of the parent societies. Clearly, the European society had commodities that Aboriginal people came to desire - tools, blankets, other cloth and dogs - and the Aboriginal people had access to large quantities of game to supply the new colony with food. The establishment of a state market for kangaroo meat opened this possibility and Aboriginal people soon came to see the 'technological' benefit of dogs for hunting - which were hitherto absent in Tasmania, unlike mainland Australia - and quickly adopted this means and also began breeding dogs for sale. Dogs were essential for large-scale hunting since firearms were relatively primitive and not in good supply. 
Nevertheless, the essential nature of Tasmanian Aboriginal society, while obviously strongly impacted at this boundary with the European world, remained a foraging, subsistence production system until the growing settler colony began to assert its power into wider areas of the island and the state moved to seize the full potential of the land resource. Then Aboriginal people were completely marginalised or massacred and survived only as a mestizo population. There is scant evidence of proletarianisation of the original population.

Thus, some Aboriginal people were able to adapt for a period to the powerful presence of European groups and their production system by, in effect, innovating a hybrid form of production based on exchange. This hybrid form developed and evolved for about 15 years until swept away from the mid-1820s by the Tasmanian settler state and its capitalist coalitionists. This story has similarities with cases of hybrid production on the grasslands and in the forests of North America and Argentina ${ }^{7}$ in the eighteenth and early to mid-nineteenth centuries.

Jon Altman has done much to describe cases of hybridity within contemporary 'remote' Australia. His description of the Bawinanga Aboriginal Corporation (BAC), for example, and its Indigenous context in central Arnhem Land, is a case of the intersection of customary, market and state sectors in which the customary zone of economic activity is adapted in part to the demands of market and state.

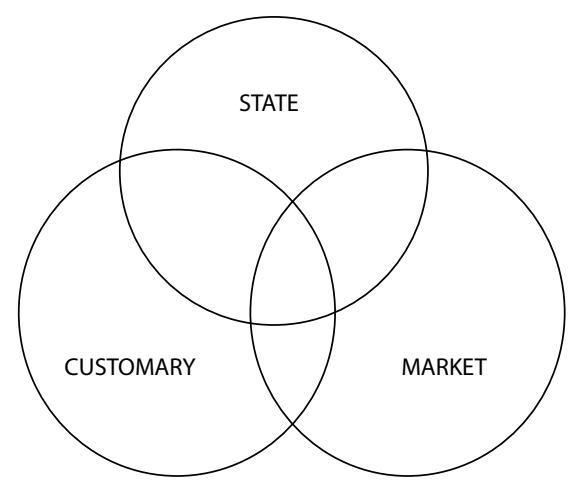

Figure 1.3 Altman's Venn diagram of hybridity ${ }^{8}$

7 The Argentine case of frontier cattle hunting is particularly striking, in which a large-scale trade developed on the basis of vast herds of feral cattle on the pampas that became the chief resource of indigenous and mestizo groups. The militarisation of the frontier through the competition for this rich resource and later the settler conquests of indigenous lands played a crucial role in Argentine nation building, politics and civil wars until the present. The indigenous inhabitants of Argentina were decimated by settler conquests and today they are largely marginalised and impoverished, representing less than 1 per cent of the total population.

8 The most recent articulation of the construct is in Altman (2010). 
Altman provides an ideal-typical description of the three-sector intersection of state, market and customary domains, as in Figure 1.3. A static description of such a regime would concentrate on the areas of intersection, why and how they came about, and how they operate and are regulated.

While there is in reality no 'pure' market, state or customary sector in such contexts as these two cases, each of the segments contains, at least in theory, a partially distinct form of activity with varying combinations of customary, state and market-based determination. The point of the idealisation is to focus attention on the central issues about such hybrid production forms, as indicated previously, which are their agential and dynamic characters: to what extent were/are Indigenous people able to innovate, develop and remain in control of these articulations in a context of powerful external forces; and are they more or less stable forms or rapidly changing transitional forms? The historical record varies, of course, but the roles of the state and the market in settler societies are obviously crucial. In the case of the BAC, Altman shows that there have been vicissitudes in its prosperity and capacity but it has shown resilience over recent decades and the future outlook seems positive (Altman 2005b).

We have to be fully cognisant of a fundamental fact about all modern societies generally and especially settler societies from the eighteenth century onwards, which is that these are very dynamic and fluid, rapidly evolving capitalist societies with a powerful impetus to proletarianisation and economic development on the basis of the world market. The roles of traditional and local (non-capitalist or quasi-capitalist peasant-based) socioeconomic structures were essentially non-existent within the settler domains, once they became established as such from the eighteenth century, unlike in either their European or their indigenous backgrounds. Settler processes were land-grab 'clearances' and rapaciously profitable resource-extraction economies. The capacity of indigenous resistance in a socioeconomic sense was very limited and insofar as it happened it was only in 'remote' and 'difficult' regions that were less desirable to capitalist metropolitan interests.

\section{On the Dialectic of Historical Evolution in Settler Societies: From description to explanation?}

What we have with Boyce's and Altman's accounts are perceptive descriptions of Indigenous hybrid agency in the face of enormous difficulty in 'hard places' (Pearson's 2009 term). But 'hard places' do not always remain 'hard', as the rapid penetration of pastoral capitalism into the Van Diemen's Land Midlands showed and as the development of tourism in the Central Australian desert shows. While hybridity might be the only viable response by Pearson's 'serious' 
Aboriginal people to the bad choices that confront them in remote areas, in other areas - older country towns, new mining towns and inner suburbswhere marginalisation rules, the hybridisation possibility is no longer open. Other responses and outcomes are occurring.

In the particular case of hybrid forms, our theoretical approach must be able to reveal the dynamics of the shifting boundaries between the three sectors and the actual or likely outcome of a severe erosion or collapse between the boundaries with the decline or disappearance of the customary sector in many cases. Once severely eroded, is the customary sector able to be reactivated sufficiently in order to form the cornerstone of a new hybridity? Without a vibrant customary sector, such a production form is not possible, of course. The possibility and strength of customary activity depend on many local factors. In the BAC case that Altman discusses, it seems that its capacity to remain viable and strongly supported by its inhabitants is in fact somewhat tenuous. He identifies several corrosive factors or potentials. And even if it does thrive it is perhaps the exception that helps to prove the rule of customary erosion throughout remote Australia to the extent that viable hybrid forms might no longer be able to be reactivated in many locales. On the other hand, the strength of some particular market-focused activity in some contexts, such as the Central Australian Indigenous art movement, could provide (and perhaps is providing) the necessary foundation for the survival and even revival of the customary sector in some places. ${ }^{9}$ But as Marx said long ago, trade and capital are solvents that erode all non-capitalist forms that enter into the orbit of capital. The power of the income and thence capital flowing from the art movement and from mining royalties has a significant impact on Australian Indigenous communities.

Beyond description, then, we must have theory in all areas of social science. The most fundamental aspect of theory is about the forces of social change or historicity. At its most abstract is the theory of dynamics and evolution of all social forms; the constancy of fundamental and rapid social change, and the often bewildering experience of it, is the central reality of ultra-modernity today. Can any socio-cultural-economic form-especially Indigenous, local, regional forms - remain integral and resistant to these forces? The long-run process of social change and transformation or, to put it another way, the history of societalisation, is a history of social evolution via complex processes of reproduction, divergence, adaptation, collapse, conquest, hybridisation and fusion. Indigenous people are necessarily no more or less subject to these forces than any other communities. The issues are about the degree and capacity of individual and collective agency and how those can be sustained and developed under the difficult circumstances of global capitalism.

9 As Jon Altman has pointed out recently: 'The indigenous visual arts sector in remote Australia is probably the best documented exemplar of intercultural production in the hybrid economy...The production and marketing of art sits squarely in the intersection of customary, state and market sectors' (Altman 2010). 
All of the adaptations, collapses, conquests, hybridisations and fusions of history have produced the evolutionary tree of societalisation. But there is a marked contrast between biological and social evolution: the first is through genetic drift due to mutation combined with the separation of alleles so that they diverge over millions of years; the second is through the dialectical processes of transformation through imperfect social reproduction leading variously to supersession, separation, conquest, hybridisation and fusion. In the modern world, separations become impossible, so the scope of societalisation via hybridity has greatly narrowed and is perhaps closing. Henceforth societalisation as the world has known it for millennia might no longer be possible. This is a momentous consequence of capitalist globalisation. This does not mean that rapid social change will not occur but it has to be via endogenous local processes of evolution within the global system.

The dialectics of the global system of ultra-modernity, with its massive interconnectedness, its powerful systems and hierarchies of self-understanding, education and knowledge, and its growing devolution and even collapse of agency downwards from the interstate system, are such that transformations and supersessions become increasingly processes of local collective agency and design. In this context, the meaning of indigeneity changes and new alliances between groups can be constructed on the basis of the creation of new local institutions and new local practices. That they will be hybrids of the old customary-based kind seems doubtful but the future is always largely unknown.

\section{References}

Altman, J. 2004. Economic development and Indigenous Australia: contestations over property, institutions, and ideology. The Australian Journal of Aboriginal and Resource Economics 48 (3): 513-34.

Altman, J. 2005a. Development options on Aboriginal land: sustainable Indigenous hybrid economies in the twenty-first century. In L. Taylor, G. K. Ward, G. Henderson, R. Davis and L. A. Wallis (eds), The Power of Knowledge. Canberra: Aboriginal Studies Press.

Altman, J. 2005b. Economic futures on Aboriginal land in remote and very remote Australia: hybrid economies and joint ventures. In D. Austin-Broos and G. Macdonald (eds), Culture, Economy and Governance in Aboriginal Australia. Sydney: University of Sydney Press.

Altman, J. 2005c. The Indigenous hybrid economy: a realistic sustainable option for remote communities? Paper, 26 October, Australian Fabian Society, Melbourne. 
Altman, J. 2007. Alleviating poverty in remote Indigenous Australia: the role of the hybrid economy. Development Bulletin (72).

Altman, J. 2009. Beyond closing the gap: valuing diversity in Indigenous Australia. CAEPR Working Paper No. 54/2009, Centre for Aboriginal Economic Policy Research, Australian National University, Canberra.

Altman, J. 2010. What future for remote Indigenous Australia? Economic hybridity and the neoliberal turn. In M. Hinkson and J. Altman (eds), Culture Crisis: Anthropology and politics in Aboriginal Australia. Sydney: UNSW Press.

Altman, J., Buchanan, G. and Biddle, N. 2006. The real 'real' economy in remote Australia. In B. H. Hunter (ed.), Assessing the Evidence onIndigenous Socioeconomic Outcomes: A focus on the 2002 NATSISS. CAEPR Research Monograph 26. Canberra: ANU E Press.

Austin-Broos, D. 2003. Places, practices, and things: the articulation of Arrernte kinship with welfare and work. American Ethnologist 30 (1): 118-35.

Belich, J. 2009. Replenishing the Earth: The settler revolution and the rise of the Anglo-world, 1783-1939. Oxford: Oxford University Press.

Blaser, M., Feit, H. A. and McRae, G. (eds) 2004. In the Way of Development: Indigenous peoples, life projects and globalization. London: Zed Books.

Boyce, J. 2009. Van Diemen's Land. Melbourne: Black Inc.

Denoon, D. 1983. Settler Capitalism: The dynamics of dependent development in the southern hemisphere. Oxford: Oxford University Press.

Howitt, R., Connell, J. and Hirsch, P. (eds) 1996. Resources, Nations, and Indigenous Peoples. Melbourne: Oxford University Press.

Jentoft, S., Minde, H. and Nilsen, R. (eds) 2003. Indigenous Peoples: Resource management and global rights. Delft: Eburon.

Kapchan, D. A. and Strong, P. T. 1999. Theorizing the hybrid. Journal of American Folklore 122 (445): 239-53.

Kraidy, M. K. 2005. Hybridity, or the Cultural Logic of Globalization. Philadelphia: Temple University Press.

Levitus, R. 2009. Aboriginal organisations and development: the structural context. In J. Altman and D. Martin (eds), Power, Culture, Economy: Indigenous Australians and mining. Canberra: ANU E Press. 
Indigenous Participation in Australian Economies II

Lloyd, C. 2002. Regime change in Australian capitalism: towards a historical political economy of regulation. Australian Economic History Review 42 (3): 238-66.

Lloyd, C. 2010a. The coming of the Anglo-world; a critical appreciation of Belich's 'Replenishing the Earth'. New Zealand Journal of History 44 (1).

Lloyd, C. 2010b. The emergence of Australian settler capitalism in the nineteenth century and the disintegration/integration of Aboriginal societies: hybridisation and local evolution within the world market. In I. Keen (ed.), Indigenous Participation in Australian Economies: Historical and anthropological perspectives. Canberra: ANU E Press.

Lloyd, C. 2012. Institutional patterns of the settler societies: hybrid, parallel, and convergent. In C. Lloyd, J. Metzer and R. Sutch (eds), Settler Economies in World History. Leiden: Brill.

Lloyd, C. and Metzer, J. 2012. Settler colonization and societies in world history: patterns and concepts. In C. Lloyd, J. Metzer and R. Sutch (eds), Settler Economies in World History. Leiden: Brill.

Lulka, D. 2009. The residual humanism of hybridity: retaining a sense of the earth. Transactions of the Institute of British Geographers [NS] (34): 378-93.

Marx, K. 1986. Outline of the Critique of Political Economy (Rough Draft of 1857-58). In K. Marx and F. Engels, Collected Works. Volume 28. London: Lawrence and Wishart.

Moran, A. 2005. White Australia, settler nationalism and Aboriginal assimilation. Australian Journal of Politics and History 51 (2): 168-93.

Nairn, T. 2009. Hybridity, not district 10. open Democracy, 10 September 2009, <http://www.opendemocracy.net/>

Nederveen Pieterse, J. 1998. Hybrid modernities: mélange modernities in Asia. Sociological Analysis 1 (3): 75-86.

Nederveen Pieterse, J. 2001. Hybridity: so what? Theory, Culture and Society 18 (2-3): 219-45.

Pearson, N. 2009. Radical Hope: Education and equality in Australia. Quarterly Essay 35. Melbourne: Black Inc.

Peers, D. M. 2007. Gunpowder empires and the garrison state: modernity, hybridity, and the political economy of colonial India, circa 1750-1860. Comparative Studies of South Asia, Africa and the Middle East 27 (2): 245-58. 
Rock, D. 1985. Argentina: From Spanish colonization to the Falklands War. Berkeley: University of California Press.

Runciman, W. G. 1983. A Treatise on Social Theory. Volume I: The methodology of social theory. Cambridge: Cambridge University Press.

Salomons, C. 2006. Hybrid historiography: pre- and post-conquest Latin America and perceptions of the past. Past Imperfect 12: 1-33.

Stewart-Harawira, M. 2005. The New Imperial Order: Indigenous responses to globalization. London: Zed Books.

Stross, B. 1999. The hybrid metaphor: from biology to culture. Journal of American Folklore 122 (445): 254-67.

Weaver, J. 2003. The Great Land Rush and the Making of the Modern World, 1650-1900. Montreal: McGill-Queen's University Press.

Whatmore, S. 2002. Hybrid Geographies: Natures, cultures, spaces. London: Sage.

Ziliak, S. T. and McCloskey, D. N. 2008. The Cult of Statistical Significance. Ann Arbor: University of Michigan Press. 